\title{
ディーゼルコジェネ排気中の $\mathrm{CO}_{2}$ を導入した 微細藻類の培養と藻油燃料生産
}

\author{
岩井 慎吾*1，古川 丈晴*1，山根 浩二*2 \\ 河崎 澄*3, 小坂田 潔*4
}

\section{Micro-algae cultivation and algae-oil fuel production by enrich $\mathrm{CO}_{2}$ introduction from diesel co-generation system}

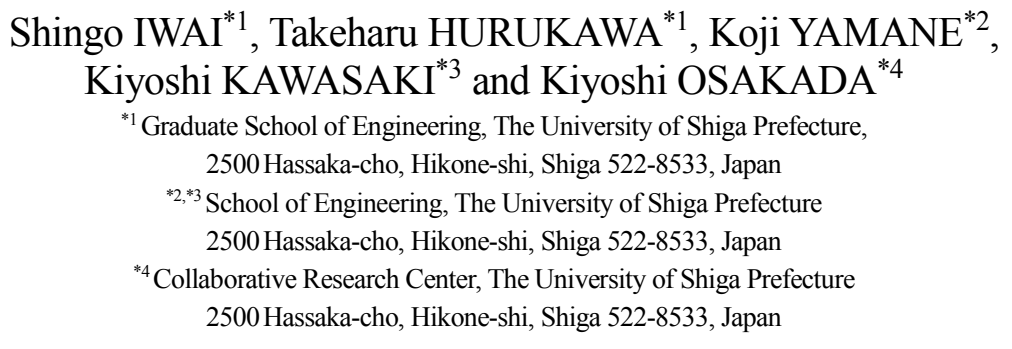

Received: 30 August 2016; Revised: 21 December 2016; Accepted: 26 January 2017

\begin{abstract}
The tri-generation system is the high efficiency of the system which utilizes not only the electricity and heat from an engine co-generation system, but also $\mathrm{CO}_{2}$ in the exhaust gas as a resource for growing plants or micro-algae. In our previous study, we demonstrate the mass production of algal-oil at enriched $\mathrm{CO}_{2}$ aeration under the sunlight condition. In this study, we collected $\mathrm{CO}_{2}$ in the diesel engine exhaust of co-generation system and introduced the enriched $\mathrm{CO}_{2}$ aeration in cultivation of microalgae, Scenedesmus dimorphus, in photo bioreactors. In addition, fuel property of the oil extracted and treated by the super-heated methanol vapor method was analyzed. From the experimental result, it was shown that the aeration of enriched $\mathrm{CO}_{2}$ of diesel engine exhaust is effective to increase algal cell density, and fuel property of FAME produced from microalgae is improved by the super-heated methanol vapor method. Also, it was estimated that the super-heated methanol vapor method is effective to reduce the energy consumption for fuel production.
\end{abstract}

Key words : Micro-algae oil, Tri-generation system, Biofuel, $\mathrm{CO}_{2}$

\section{1. まえがき}

近年，再生可能なエネルギ一資源の一つである植物由来のバイオ燃料の開発と利用が進められている．然料の 燃焼により排出される $\mathrm{CO}_{2}$ は植物の光合成により吸収されることから, 植物から生産されるバイオ燃料は $\mathrm{CO}_{2}$ が 増加しないカーボンニュートラルの特性を持つ.しかし，陸上植物由来のバイ才燃料は食料との競合や肥沃な土 地が必要などの問題がある。そこで食料と競合せず，肥沃な土地が不要で，また単位面積あたりの油分生産量が 陸上植物と比較して高い微細藻類によるバイオ然料生産が注目されている(Chisti, 2007).

一般に，藻類から燃料生産までの工程は，藻類培養工程，乾燥・脱水工程，油分抽出工程，燃料化工程からな る。このように工程が多いために然料生産コストが高くなり，実用化には各工程でのコスト低減が不可欠となっ

No.16-00389 [DOI:10.1299/transjsme.16-00389], J-STAGE Advance Publication date: 3 February, 2017

*1 滋賀県立大学大学院工学研究科（干522-8533 滋賀県彦根市八坂町 2500)

*2 正員, フェロー, 滋賀県立大学工学部

*3 正員, 滋賀県立大学工学部

*4 滋賀県立大学産学連携センター

E-mail of corresponding author: kawasaki@mech.usp.ac.jp 
ている，そのため，低コスト化を目指した効率的な培養方法，高効率な培養装置や油分含有率の高い新種株の開 発が行われている（田中他, 2010）（横山, 2010）（若山, 2012）.

筆者らは, ディーゼルコジェネレーションシステムから得られる熱と電気の利用に加えて, エンジン排気中の $\mathrm{CO}_{2}$ を資源ととらえ, それを藻類培養に活用し, 得られる藻油からバイオ燃料を生産するトリジェネレーション システムの構築を目指している（古川他, 2015). 本研究では, まず，ディーゼル排気中の $\mathrm{CO}_{2}$ を選択的に連続し て化学吸収・再生し, 藻類培養に用いた場合の培養への効果を検証した. さらに, 藻油の抽出方法として過熱义 タノール蒸気法（石川他,2005）（山根他,2006）を用いて, 脱水・乾燥工程を省き, 油分抽出と同時に触媒を使わ ずに燃料である脂肪酸メチルエステル（Fatty acid methyl ester, FAME）に変換する新規手法を提案すると共に，そ のエネルギー収支解析を行った。

\section{2. コジェネ排気中の $\mathrm{CO}_{2}$ が微細藻類培養に及ぼす影響}

\section{$2 \cdot 1$ 使用藻体および培養方法}

本研究で使用した藻類は, 図 1 に示寸通称イカダモと呼ばれる, 学名 : Scenedesmus dimorphus (Turpin) Kützing (国立環境研究所（NIES）, 株番号 NIES-119）（以下，セネデスムスと略す）である. セネデスムスは，生育温度 が $20{ }^{\circ} \mathrm{C} \sim 35{ }^{\circ} \mathrm{C}$, 生育できる $\mathrm{pH}$ の幅が比較的広く培養が容易で, 外部に漏れても生態系に影響を与えない. ま た, 乾燥重量の約 2 割が脂質で, 主に脂肪酸であり, FAME 製造に適している.

培養実験は, コンタミネーションによる藻類の全滅を防ぐために小規模, 中規模, 大規模の 3 段階でスケール アップしながら行なった. まず, 小規模培養は, 植物育成用温室 (アズワン株式会社, プレートヒーターセット) 内部にて $300 \mathrm{~mL}$ の三角フラスコを用いて行なった．温室内には，ヒータとファンが取り付けられており $20^{\circ} \mathrm{C} \sim$ $25{ }^{\circ} \mathrm{C}$ 保たれる. 中規模培養は, 室温 $21{ }^{\circ} \mathrm{C}$ 屋内で $2 \mathrm{~L}$ の透明容器を 15 本用いて行なった. また, 小規模・中 規模培養の実施中は, マグネットポンプを用いて常時空気を通気するとともに, 植物育成用蛍光灯（NEC,ビオル ックス $20 \mathrm{~W} \times 2 ）$ を培養容器の上部に設置して微細藻類の光合成の為の光源とした.

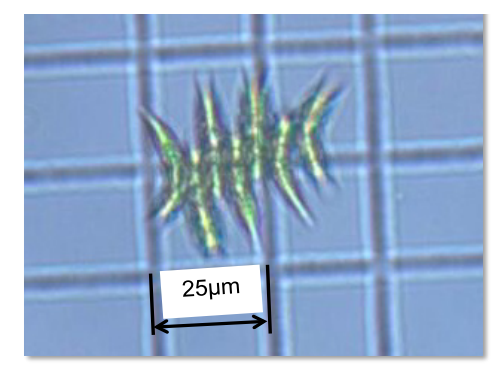

Fig.1 Microscopic photograph of Scenedesmus.

つぎに屋外での大規模培養には, 図 2(a)に示寸アクリル製で容量 $30 \mathrm{~L}$ のエアリフトクローズドカラム式フォ トバイオリアクタ（以下 PBR と略す）を設計・試作し, 温室（株式会社ピカコーポレーション, WP-15, 幅 1747×奥行 2600×高さ1600）内部に 9 台設置して培養を行った．まず，中規模培養で得られた藻体は，すべて 1 台の PBRに移して所定の期間培養した，それを，他の 8 台の PBRに株分けしてさらに培養することで，燃料製 造用の藻体を得た。 


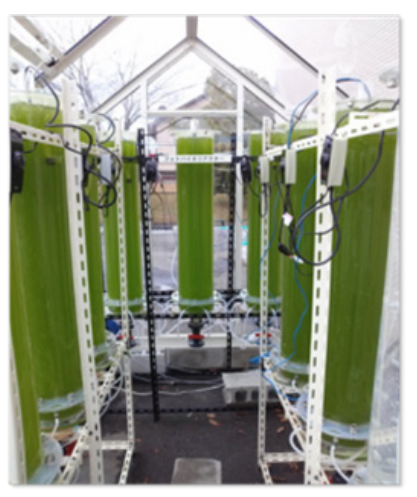

(a) PBR in a greenhouse

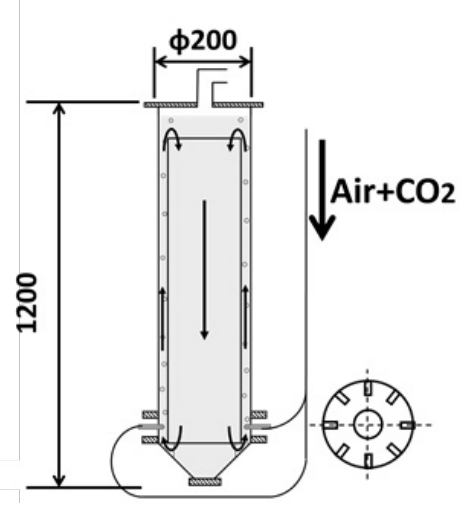

(b) PBR

Fig.2 Large scale cultivation with photo-bio reactors.

PBR は，図 2(b)に示すような二重管構造になっており，コンプレッサから $2.5 \mathrm{~L} / \mathrm{min}$ で送られる空気を，容器 下部の側面から外側筒と内側筒の間に常時通気することでエアリフト式のかくはんを行い，藻類を循環させるこ とができる. また，水温が $40{ }^{\circ} \mathrm{C}$ 以上にならないように冷却管を設置する一方，水温が $20{ }^{\circ} \mathrm{C}$ 以下にならないよ うに電気ヒータ（ジェックス株式会社，メタルオート 120）を設置した.

培養実験は, NIES で公表されている一般的なセネデスムス用の培地である培地 C と同じ組成になるよう試薬 を調合して培地として用い実施した。培養実験における微細藻類の藻体濃度は, 分光光度計 (アズワン株式会 社, ASV11D (1-1814-01) ) で, 吸光光度法に基づいて測定した培養液の光学濃度（Optical Density，以下 OD） により評価した．なお，測定の際はクロロフィルの吸収波長である $750 \mathrm{~nm}$ に合わせ(Widjaja et al., 2009), イオン 交換水の $\mathrm{OD}$ 值を基準点とした.

\section{$2 \cdot 2$ 排気中 $\mathrm{CO}_{2}$ の選択的吸収 - 再生および導入方法}

ディーゼル排気中の $\mathrm{CO}_{2}$ は，モノエタノールアミン（以下 MEA）水溶液による化学吸収法（井亀他, 1994） を用いて, 分離回収・再生を行なった．MEA 水溶液を用いた $\mathrm{CO}_{2}$ の回収および再生は，主に以下の反応式によ って進行する.

$$
\begin{aligned}
& 2 \mathrm{R}-\mathrm{NH}_{2}+\mathrm{CO}_{2} \rightleftarrows \mathrm{R}-\mathrm{NHCOO}^{-}+\mathrm{RNH}_{3}{ }^{+} \\
& \mathrm{R}-\mathrm{NH}_{2}+\mathrm{CO}_{2}+\mathrm{H}_{2} \mathrm{O} \rightleftarrows \mathrm{HCO}_{3}{ }^{-}+\mathrm{RNH}_{3}{ }^{+}
\end{aligned}
$$

式(1)(2)における R は， $\mathrm{C}_{2} \mathrm{H}_{4} \mathrm{OH}$ である. MEA 水溶液は, $40 \sim 50{ }^{\circ} \mathrm{C}$ の比較的低温で上式の右側へ向かう発熱反応 によって $\mathrm{CO}_{2}$ を吸収し, $100 \sim 120{ }^{\circ} \mathrm{C}$ 高温で式の左側へ向かう吸熱反応によって $\mathrm{CO}_{2}$ を放出する. 実験には MEA （ナカライテスク株式会社，JIS 試薬特級）を水道水で 50 vol\%に希釈したものを用いた.

図 3 は, 排ガス中の $\mathrm{CO}_{2}$ 選択吸収・再生装置の概略図を示している.ディーゼルコジェネレーション (YANMAR $\mathrm{CP} 10 \mathrm{VB}$, 出力 $9.9 \mathrm{~kW})$ からの排気は, $\mathrm{CO}_{2}$ 吸収塔(1)に下部より入り, 塔上部から流入する約 $40{ }^{\circ} \mathrm{C} の \mathrm{MEA}$ 水溶 液と向流接触する. これにより, 排気中の $\mathrm{CO}_{2}$ が MEA 水溶液に吸収される. $\mathrm{CO}_{2}$ を吸収した MEA 水溶液は, エ ンジンから出る温水 (約 $80^{\circ} \mathrm{C}$ ) との熱交換器 $\mathrm{A}(2)$, および熱回収用の熱交換器 $\mathrm{B}(3)$ を経て $\mathrm{CO}_{2}$ 再生器(4)に送ら れる. $\mathrm{CO}_{2}$ 再生器(4)および加圧経路(5)において, $\mathrm{MEA}$ 水溶液は電気ヒータで $110{ }^{\circ} \mathrm{C}$ に加熱されて $\mathrm{CO}_{2}$ が再生さ

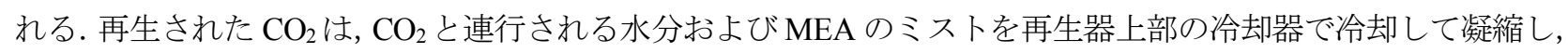
除去した後にガスバッグに捕集する. $\mathrm{CO}_{2}$ 再生後の MEA 水溶液は水道水との熱交換器 $\mathrm{C}$ (7)を経て, 再び吸収塔 に導かれる．実験の結果，本装置においては，排ガス中の $\mathrm{CO}_{2}$ の約 $23 \%$ 吸収でき，そのうちの約 $39 \%$ を再生 することができた. 本研究の微細藻類培養実験に対する $\mathrm{CO}_{2}$ 量としては十分であるが，今後，大規模に培養を行

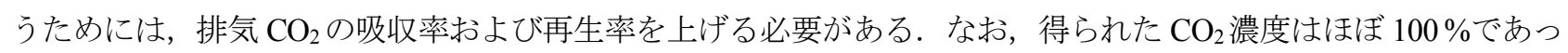
た. 


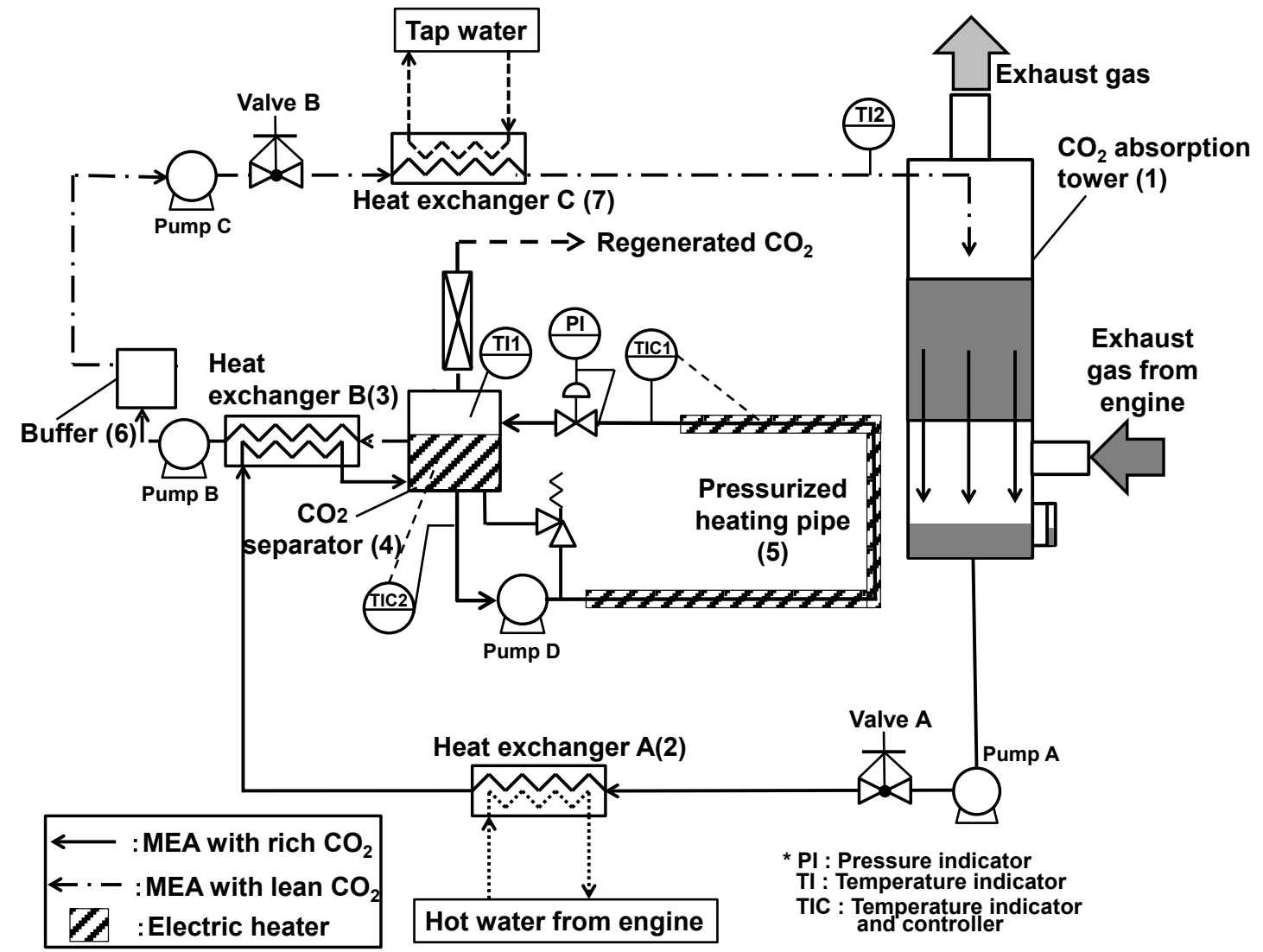

Fig.3 Flow sheet of $\mathrm{CO}_{2}$ selective chemical absorption and regeneration process with an aqueous solution of mono-ethanolamine.

\section{$2 \cdot 3$ 排気中 $\mathrm{CO}_{2}$ が培養に及ぼす影響}

前報から，微細藻類培養時にボンべから富化 $\mathrm{CO}_{2}$ を導入することで，藻類の成長が促進されることがわかって いる(古川他，2015). 本報では，コジェネ排気から回収した $\mathrm{CO}_{2}$ を富化導入し実験を行なった。実験では，ガス バッグに捕集した排気中 $\mathrm{CO}_{2}$ を，チューブポンプを用いて $0.05 \mathrm{~L} / \mathrm{min}$ の流量で PBR 内の通気に濃度 $2 \%$ て混ぜて 導入し藻類を培養した，図 4 は，培養期間に対する $\mathrm{OD}$ 值を示す．図のように， $\mathrm{CO}_{2}$ を富化導入することによっ て, 藻体濃度が増加し, 成長が促進している.これは, 前報でのボンべ標準ガスで $\mathrm{CO}_{2}$ を富化導入した場合と同 じである.

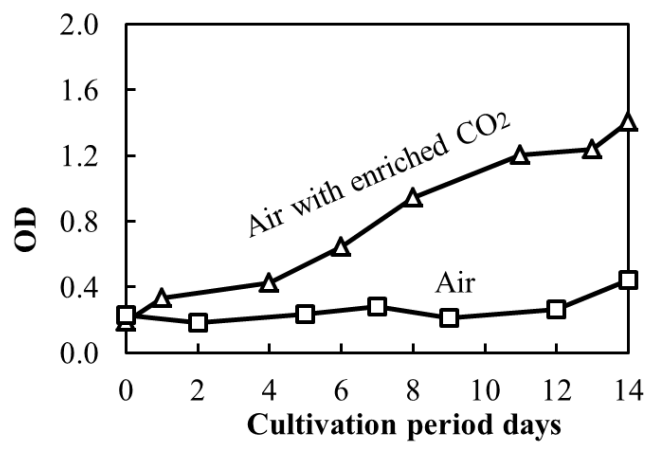

Fig.4 Time history of microalgae cell density. By introducing $\mathrm{CO}_{2}$ collected from an engine exhaust gas into aeration air, the propagation of micro-algae is promoted. 


\section{3. 二段階過熱メタノール蒸気法による燃料生産}

\section{$3 \cdot 1$ 実験装置および実験方法}

過熱メタノール蒸気法 (Super-heated methanol vapor method, SMV 法) とは, 常圧下でメタノールを沸点 $\left(64.7{ }^{\circ} \mathrm{C}\right)$ より高い温度 $200 \sim 290{ }^{\circ} \mathrm{C}$ まて過熱した過熱蒸気を原料油と接触させることで，無触媒で脂肪酸卜リグリセリド のエステル交換反応と遊離脂肪酸のエステル化反応を行う FAME 生産方法である. 著者らは既報において, SMV 法を粒子状の米ヌカに適用すれば, 油分の抽出と FAMEへの変換を同時に行えることを示した(小坂田他,2013). この手法を，微細藻類からの燃料生産に適用すれば，脱水・乾燥工程を含まない低コストの生産を実現できる可 能性がある。

本研究では，SMV 法を二段階に分けて行い，油分抽出と燃料化を試みた。まず，主に油分抽出を目的とする一 段目の反応にはボウル式反応器を用いた. 反応器の詳細は文献（小坂田他, 2013）にゆずる. 一段目の反応では, 反応器内に充填した含水藻類（含水率 $95 \mathrm{wt} \%$ ）を $260{ }^{\circ} \mathrm{C}$ まで昇温し，そこに $200{ }^{\circ} \mathrm{C}$ 過熱メタノール蒸気を通 気することで，藻体から油分（粗油）を抽出した，図 5 は，二段階目の装置概略図であり，これを用いて一段目 で抽出した粗油の燃料化を行う。反応器はカラム式構造となっており, 過熱メタノール蒸気との接触時間を長期 化することができ, 反応器気相の温度を調節することで, 反応物を蒸留により分離することが可能である. また, 外側に $80{ }^{\circ} \mathrm{C}$ の温水を循環させた分離器により流出物中のメタノールを分離し, 密度差を用いて FAMEおよびグ リセリンを分離することができる.

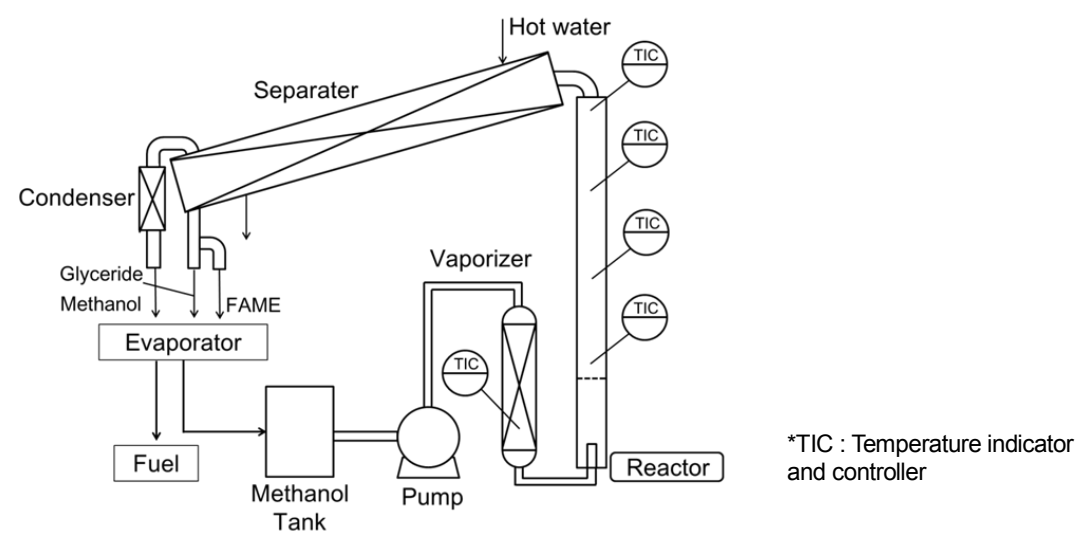

Fig.5 Schematic illustration of super-heated methanol vapor method (SMV) at 2nd stage for FAME production.

実験では，まず反応器に粗油を充填し，それを $260^{\circ} \mathrm{C}$ ま゙昇温する，つぎに， $200{ }^{\circ} \mathrm{C}$ ま゙昇温した過熱メタ， 一ル蒸気を $250 \mathrm{ml} / \mathrm{h}$ で粗油と接触させることで反応させた．流出してきた反応物はメスシリンダーに溜め，一 時間おきに回収しエバポレータによりメタノールを除去した。これを一時間あたりの流出物質量が $1 \mathrm{~g}$ 以下にな るまで行なった。

\section{$3 \cdot 2$ 二段階 SMV 法を適用した場合の油分の燃料性状}

ここでは一段目のSMV で得た粗油に，二段目のSMVを行なって得られた各流出油の燃料性状の分析を行っ た. 試料には，次に示す S1〜S4 の 4 検体を用いた. S1 は一段目の SMV により得た粗油を原料藻類の培養条件 を指定せず混合したもの，S2 はS1 に二段階目の SMV を適用しFAME 流出口より回収した反応物，S3 はメタ～ 一ル流出口から回収したメタノール中に残留していた反応物, S4 は反応器内に残留している反応物を常温のメタ ノールで洗浄し回収したものである. なお，全ての検体はエバポレータにより残留メタノールを完全に除去して から分析を行った. 
表 1 は，S1，S2，S3，S4 の燃料性状を，図 6 は，FAME，グリセリド類，遊離脂肪酸(Free fatty acid, FFA), そ の他の質量割合をそれぞれ示している．なお，表 1 の動粘度において，S1 は粘度が高かったため，S3 は試料が 少なかったため計測不能であった. また, 曇り点 $(\mathrm{CP})$ においても, S3 以外は透明度が低かったため, 測定ができ

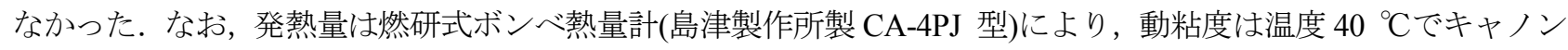
フェンスケ(柴田科学株式会社製)により, 酸価 AV およびヨウ素価 IV は滴定による公定法により, また残留炭素 分は試料を濃縮せずにそのままをミクロ残炭計(田中科学機器製作株式会社製 ACR-M3)によってそれぞれ測定し た. グリセリド類は，ガスクロマトグラフ(島津製作所製 GC-2010 型, 検出器 : FID, 検出器温度 : $380{ }^{\circ} \mathrm{C}$, カラ ム : ZB-5HT INFERNO，カラム温度 : 50〜380 ${ }^{\circ} \mathrm{C}$ )によって分析し，クロマトグラムのピーク面積によって組成割 合を算出した。量り点 (CP) および流動点（PP） は，自動流動点・曇り点試験器(田中科学機器製作株式会社製 MPC-102A 型)を用いて測定した.

表 1 より, S1 の粗油に比べて S2 は, 動粘度, AV, 残留炭素が改善されていることがわかる. これは，未 反応であった脂肪酸がエステル化し，FAME へ変換されたためと考えられる．また，図 $6 よ り \mathrm{~S} 2, \mathrm{~S} 3, \mathrm{~S} 4$ は，約 4〜5 割が FAME に変換されていることがわかる. これらの結果から, 多段階過熱メタノ一ル蒸気法 は燃料性状を改善する方法として有効であると言える.

Table 1 Properties of products obtained by the multistage SMV method. Kinematic viscosity, acid value (AV), carbon residue can be decreased by conducting SMV method twice.

\begin{tabular}{|l|c|c|c|c|}
\hline & 1st stage & \multicolumn{3}{|c|}{ 2nd stage } \\
\cline { 2 - 5 } & S1 & S2 & S3 & S4 \\
\hline Sample [g] & 79.3 & 14.2 & 8.7 & 22.3 \\
\hline Higher heating value [MJ/kg] & 32.0 & 36.3 & 36.3 & 37.0 \\
\hline Kinematic viscosity [mm²/s] & N.A. & 8.37 & N.A. & 8.15 \\
\hline AV [mgKOH/g] & 121 & 57.0 & 54.8 & 37.4 \\
\hline IV & 80.3 & 74.8 & 72.3 & 79.4 \\
\hline Carbon residue [mass\%] & 5.5 & 1.2 & 0.7 & 1.0 \\
\hline Mono-glyceride [mass\%] & 0.067 & 0 & 0.033 & 0.045 \\
\hline Di-glyceride [mass\%] & 0.050 & 0 & 0 & 0.012 \\
\hline Tri-glyceride [mass\%] & 0 & 0 & 0.0038 & 0 \\
\hline Free glyceride [mass\%] & 0.39 & 0.0041 & 0.063 & 0.0034 \\
\hline $\mathrm{CP}\left[{ }^{\circ} \mathrm{C}\right]$ & N.A. & N.A. & 10 & N.A. \\
\hline PP $\left[{ }^{\circ} \mathrm{C}\right]$ & 23 & 2 & 1 & 3 \\
\hline
\end{tabular}
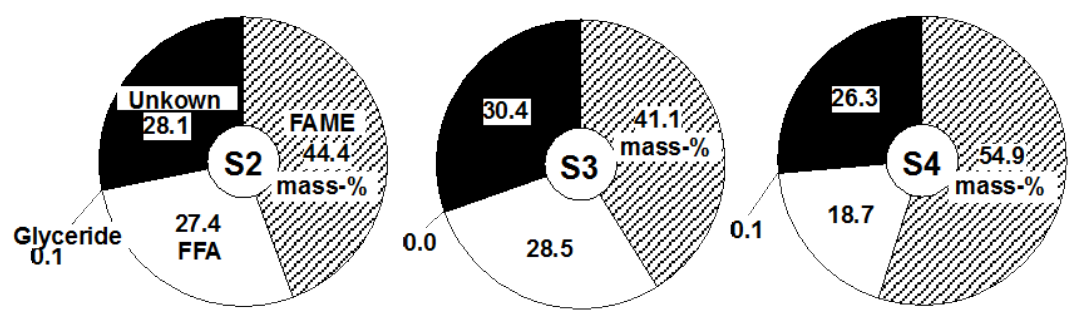

Fig.6 Composition of products obtained by the multistage SMV method. As the result of two stage SMV method, approximately $50 \%$ of algal oil can be converted to FAME. 


\section{4. トリジェネレーションおよびSMVによる藻類燃料生産のエネルギ一収支解析}

\section{$4 \cdot 1$ エネルギー収支解析方法}

本節では，得られた実験データをもとに，トリジェネレーションシステムを用いた際の藻類培養から燃料生産 までのエネルギー収支の解析を試みた。油分抽出工程においては，脱水工程の不要な SMV と脱水工程が必要な ソックスレ抽出のエネルギー収支の比較を行なった。ここでは，培養工程から燃料生産工程までの各工程で運転 時に伴うエネルギー投入量およびエネルギ一獲得量を概算し，それらのエネルギ一収支を解析した。各工程のモ デルの概略は，下記のとおりである.

培養工程では，室内培養から屋外培養に移行し培養を行う。その際，コジェネ排気中の $\mathrm{CO}_{2}$ を濃度 $2 \%$ 1 日 7.5 時間の通気を行う。コジェネ排気中の $\mathrm{CO}_{2}$ は， $\mathrm{MEA}$ による化学吸収・再生により得る。また，屋外培養では これまでのデータより, 年間を通して藻体増殖率は, $0.07 \mathrm{~g} /(\mathrm{L} \cdot \mathrm{day})$, 室内培養では $0.04 \mathrm{~g} /(\mathrm{L} \cdot \mathrm{day})$ と仮定する.

抽出工程では, SMV を用いる場合は含水状態の藻類から抽出を行い, ソックスレ抽出を用いる場合は, 前処理 として遠心分離機と凍結乾燥機で脱水を行い乾燥状態の藻類から抽出を行う。また，培養から燃料生産までの間 隔を 20 日とする. なお，エネルギ一獲得量は，抽出した然料および残椬の発熱量として算出する.

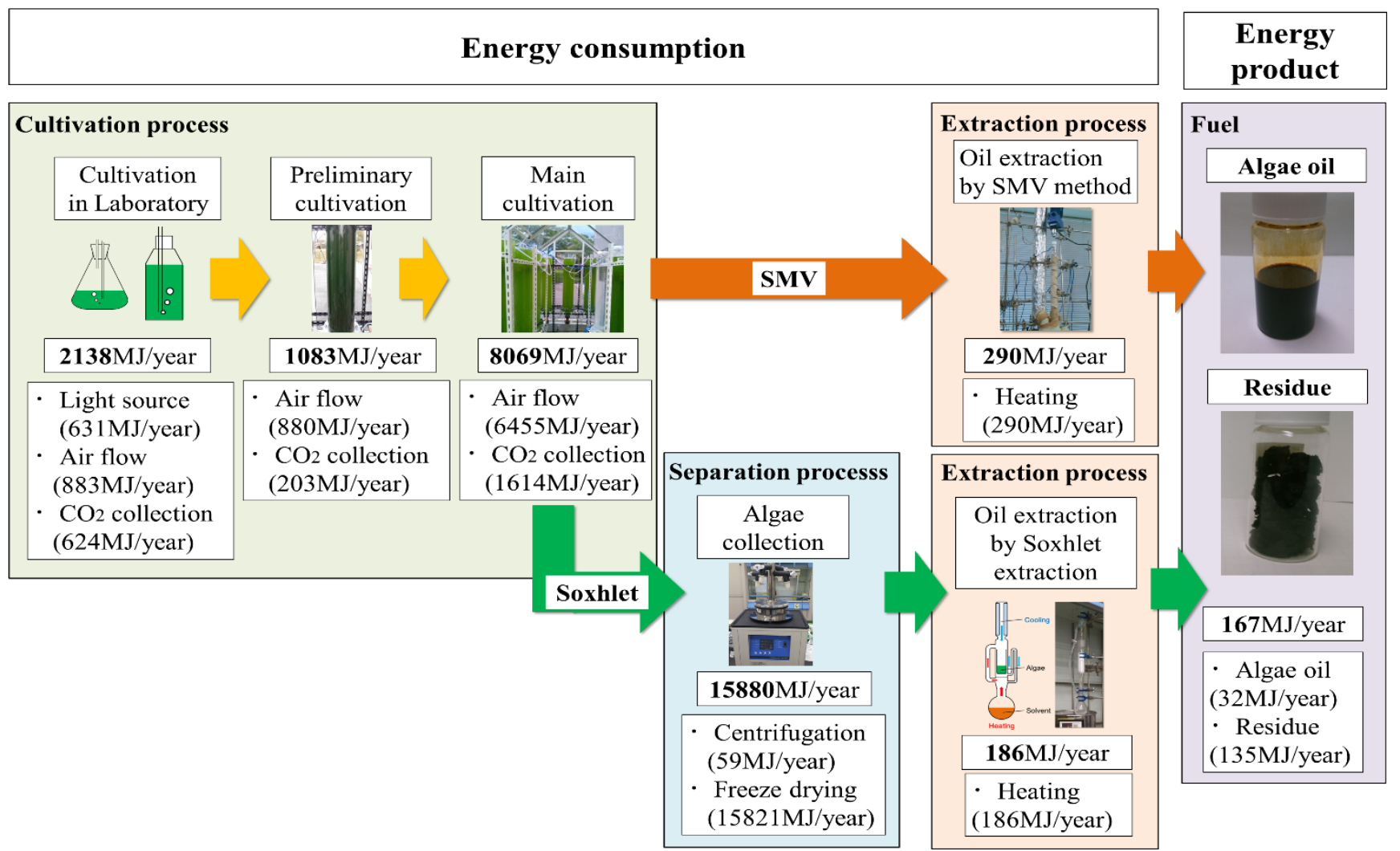

Fig.7 Energy balance investment from microalgae cultivation to fuel production. SMV method is effective to decrease the energy consumption in the oil extraction process from microalgae compared to Soxhlet extraction method, because the drying process as a pretreatment is not required.

\section{$4 \cdot 2$ エネルギー収支解析結果}

図 7 は, 本実験における藻体培養から然料製造までのエネルギー収支解析の結果を示す. 本結果は, 藻体培養, $\mathrm{CO}_{2}$ 選択的回収, 藻油抽出・燃料化の各工程に関する実験室スケール研究に基づくものである. そのため, 燃料 として獲得できたエネルギー（167 MJ/year）に比べて，各工程でのエネルギー消費の方がはるかに大きく，工程 全体のエネルギー収支を考察できる段階にはない。そこで以下では，各工程におけるエネルギー消費削減の可能 性と，燃料化に SMV 法を用いることによるエネルギー消費削減効果について述べる. 
まず，本研究の培養工程においては，空気の通気に大きなエネルギーを要したことが分かる，とくに，PBRで の培養に要したエネルギーの約 $80 \%$ が，通気に要したネルギーである。これは，使用した蓄圧式コンプレッサの

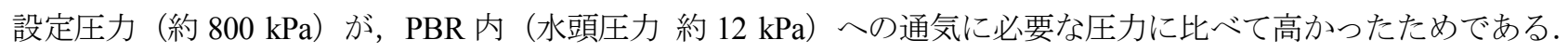
この圧縮動力は, 空気の供給圧力を必要最低限に下げることで, 本結果の約 $10 \%$ に低減できると見込まれる.

一方, $\mathrm{CO}_{2}$ 富加による培養期間短縮のエネルギ一削減効果を得るためには, エンジン排気からの $\mathrm{CO}_{2}$ 選択的回 収に要するエネルギー消費をさらに削減する必要がある. 本研究の $\mathrm{CO}_{2}$ 回収工程における主なエネルギー消費は, 図 3 に示した $\mathrm{CO}_{2}$ 再生器(4)において, MEA 水溶液を $110{ }^{\circ} \mathrm{C}$ まで加熱するために用いた電気ヒータの電力消費 である. 加熱に電気ヒータを用いた理由は, 使用したコジェネレーションシステムの熱出力が, 約 $80^{\circ} \mathrm{C}$ 温水出 力のみであり, この温水だけでは MEA 水溶液を $110{ }^{\circ} \mathrm{C}$ まで加熱できないためである. したがって, エンジン排 気の熱を $110^{\circ} \mathrm{C}$ 以上の熱媒体, または MEA 水溶液と直接熱交換できるように, コジェネレーションシステムを改 善すれば $\mathrm{CO}_{2}$ 回収に要するエネルギー消費を改善できる見込みがある.

次に, 藻体からの燃料製造の工程に着目寸る. 藻油抽出にソックスレ法を用いる場合, その前処理である脱水・ 乾燥工程（遠心分離と冷凍乾燥）に多くのエネルギーが必要であることがわかる. 一方, 本研究で提案する SMV 法を用いた燃料製造では, 含水藻体に過熱メタノール蒸気を直接作用させるため, 脱水・乾燥工程が不要となる. その結果, 本試算ではSMV 法を用いた場合のエネルギー消費は, ソックスレ法を用いる場合の約 $1 \%$ と見込まれ ていることから，SMV 法を用いることにより燃料製造に関するエネルギー収支が改善できると言える.

\section{5. まと め}

本研究では, ディーゼルコジェネ排気中の $\mathrm{CO}_{2}$ を微細藻類に富化導入した場合の影響と, 二段階過熱メタノー ル蒸気法により得られる燃料性状, および, トリジェネレーションシステムを用いて微細藻類を培養し, その油 分から燃料を生産するまでのエネルギー収支解析について調査した.

その結果, コジェネ排気中の $\mathrm{CO}_{2}$ を微細藻類に富化導入することで, ボンベ標準ガスで $\mathrm{CO}_{2}$ を富化導入する場 合と同様に微細藻類の成長が促進寸ることが確かめられた．また，過熱メタノール蒸気法を二段階に分けて行う ことで, 一段階目で得た粗油中の未反応の脂肪酸がエステル化しFAMEに変換したことで, 酸価や残留炭素など の燃料性状が改善される.

さらに，エネルギ一収支解析により，藻体からの藻油燃料製造工程に脱水工程が含まれると大きなエネルギー が必要であることから, 脱水工程の不要な過熱メタノール蒸気法を用いることでエネルギー収支が改善されるこ とがわかった。

\section{謝 辞}

本研究は, 文部科学省「地域イノベーション戦略支援プログラム: 電気と熱の地産地消型スマートグリッドシ ステムの開発（平成 23 年 10 月〜平成 28 年 3 月)」の助成を受けて行なった.

\section{文 献}

Chisti,Y., Biodiesel from microalgae, Biotechnology Advances, Vol.25(2007), pp.294-296.

古川丈晴, 小坂田潔, 山根浩二, 河崎澄, フォトバイオリアクタを用いた燃料微細藻類の屋外実証培養実験, 日 本機械学会 2015 年度年次大会講演論文集, G0800102 (2015), pp.1-4.

井亀優, 菅進, 平岡克英, 熊倉孝尚, モノエタノールアミン水溶液を使った充てん塔の $\mathrm{CO}_{2}$ 吸収特性, 船舶技術 研究所報告, Vol.31, No.4 (1994), pp.159-173.

石川智子, 山崎理恵, 岩本悟志, 鍋谷浩志, 小坂田潔, 宮脇長人, 相良泰行, 無触媒アルコリシス反応によるバ イオディーゼル燃料生産方法の経済性評価と原料油の価格がバイオディーゼル燃料の価格に及ぼす影響に ついて, 日本食品工学会誌, Vol.6, No.2 (2005), pp.113-120.

小坂田潔, 山根浩二, 河崎澄, 近藤千尋, 過熱メタノール蒸気法による米又カからの液体燃料の直接製造, 日本 エネルギー学会誌, Vol.92 (2013), pp.919-924. 
田中美穂，伊藤卓朗，冨田勝，オイル産生微細藻における脂質蓄積機構の解明にむけて，バイオインダストリー, Vol.27, No.6 (2010), pp.13-18.

若山樹，藻類系バイオマスを活用したエネルギー生産事業への展望，バイオインダストリー, Vol.29, No.12 (2012), pp.54-64.

Widjaja, A., Chien, C-C. and Ju, Y-H., Study of increasing lipid production from fresh water microalgae Chlorella vulgaris, Journal of the Taiwan Institute of Chemical Engineers No.40 (2009), pp.13-20.

山根浩二，河崎澄，青木岳夫，小坂田潔，鍋谷浩志，無触媒アルコリシス反応によるバイオディーゼル燃料の製 造とエンジン性能，自動車技術会論文集, Vol.37, No.6 (2006), pp.103-108.

横山伸也，微細藻類からの炭化水素の効率的回収, バイオインダストリー, Vol.27, No.6 (2010), pp.36-44.

\section{References}

Chisti,Y., Biodiesel from microalgae, Biotechnology Advances, Vol.25(2007), pp.294-296.

Furukawa, T., Osakada, K., Yamane, K. and Kawasaki, K., The outdoor demonstration of micro-algae cultivation for bio-fuel production using photo bioreactors, Proceedings of Mechanical Engineering Congress, G0800102 (2015), pp.1-4 (in Japanese).

Ikame, M., Kan, S., Hiraoka, K. and Kumakura, T., $\mathrm{CO}_{2}$ absorption characteristics of packed column using aqueous solution of monoethanolamine, Technical Report of National Maritime Research Institute, Vol.31, No.4 (1994), pp.159-173 (in Japanese).

Ishikawa, T., Yamazaki, R., Iwamoto, S., Nabetani, H., Osakada, K., Miyawaki, O. and Sagara, Y., Economic assessment on practical application of noncatalytic alcoholysis for biodiesel fuel production, Japan Journal of Food Engineering, Vol.8, No.1 (2005), pp.113-120 (in Japanese).

Osakada, K., Yamane, K., Kawasaki, K. and Kondo, C., Direct production of liquid fuel from rice bran powder by using superheated methanol vapor method, Journal of the Japan institute of energy, Vol.92 (2013), pp.919-924 (in Japanese).

Tanaka, M., Ito, T. and Tomita, M., Investigation of the mechanism for lipid accumulation in oil-rich microalgae, Bio Industry, Vol.27, No.6 (2010), pp.13-18 (in Japanese).

Wakayama, T., Prospects for energy production business utilizing the algal biomass, Bio Industry, Vol.29, No.12 (2012), pp.5464 (in Japanese).

Widjaja, A., Chien, C-C. and Ju, Y-H., Study of increasing lipid production from fresh water microalgae Chlorella vulgaris, Journal of the Taiwan Institute of Chemical Engineers No.40 (2009), pp.13-20.

Yamane, K., Kawasaki, K., Aoki, T., Osakada, K. and Nabetani, H., Biodiesel fuel production by non-catalytic alcoholysis and its engine performance, Transactions of Society of Automotive Engineers of Japan, Vol.37, No.6 (2006), pp.103-108 (in Japanese).

Yokoyama, S., Efficient recovery of hydrocarbons from microalgae, Bio Industry, Vol.27, No.6 (2010), pp.36-44 (in Japanese). 